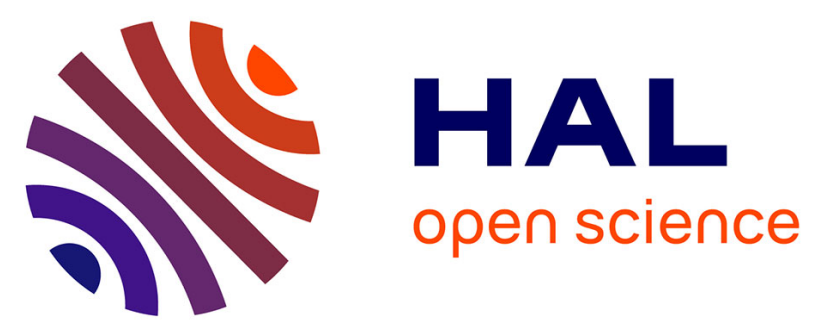

\title{
A new process of reconstructing archaeological fires from their impact on sediment: a coupled experimental and numerical approach based on the case study of hearths from the cave of Les Fraux (Dordogne, France)
} Aurélie Brodard, Delphine Lacanette-Puyo, Pierre Guibert, Francois Leveque, Albane Burens-Carozza, Laurent Carozza

\section{To cite this version:}

Aurélie Brodard, Delphine Lacanette-Puyo, Pierre Guibert, Francois Leveque, Albane Burens-Carozza, et al.. A new process of reconstructing archaeological fires from their impact on sediment: a coupled experimental and numerical approach based on the case study of hearths from the cave of Les Fraux (Dordogne, France). Archaeological and Anthropological Sciences, 2015, 8, pp.10.1007/s12520-0150250-7. 10.1007/s12520-015-0250-7 . hal-01155304

\author{
HAL Id: hal-01155304 \\ https://hal.science/hal-01155304
}

Submitted on 1 Dec 2020

HAL is a multi-disciplinary open access archive for the deposit and dissemination of scientific research documents, whether they are published or not. The documents may come from teaching and research institutions in France or abroad, or from public or private research centers.
L'archive ouverte pluridisciplinaire HAL, est destinée au dépôt et à la diffusion de documents scientifiques de niveau recherche, publiés ou non, émanant des établissements d'enseignement et de recherche français ou étrangers, des laboratoires publics ou privés. 


\title{
A new process of reconstructing archaeological fires from their impact on sediment: a coupled experimental and numerical approach based on the case study of hearths from the cave of Les Fraux (Dordogne, France)
}

\author{
Aurélie Brodard ${ }^{1}$ • Delphine Lacanette-Puyo ${ }^{2}$ - Pierre Guibert ${ }^{1} \cdot$ François Lévêque $^{3}$. \\ Albane Burens ${ }^{4} \cdot$ Laurent Carozza ${ }^{4}$
}

Received: 16 October 2014 / Accepted: 7 May 2015

(C) Springer-Verlag Berlin Heidelberg 2015

\begin{abstract}
A novel approach to the intensity of archaeological fires is proposed, based on a combination of archaeological observations and analyses of sedimentary hearths with relevant proxies obtained from using experimental combustion structures. In this work, two different structures were built and monitored. They aimed at reproducing two types of archaeological hearth morphology encountered at the Bronze Age site of the cave of Les Fraux (Saint Martin de Fressengeas, Dordogne, France). A series of fires was constructed and a large amount of data was collected: temperature curves, wood consumption and observations on substratum evolution. A numerical code for heat transfer was developed to model heat propagation from the surface to the underlying sedimentary layers, the input parameters of which were adapted to fit the thermal evolution observed with the experimental fires. We found that two archaeological
\end{abstract}

Aurélie Brodard

aurelie.brodard@gmail.com

1 IRAMAT-CRP2A (Institut de recherche sur les Archéomatériaux-Centre de Recherche en Physique Appliquée à l'Archéologie) UMR 5060 CNRS - Université de Bordeaux Montaigne, Maison de l'archéologie, Esplanade des Antilles, 33607 Pessac Cedex, France

2 I2M (Institut de Mécanique et d'Ingénierie - Bordeaux), UMR 5295 CNRS - Université de Bordeaux, 16 Avenue Pey-Berland, 33607 Pessac, France

3 LIENSs (Littoral, Environnement et Sociétés) UMR 7266 CNRS Université de La Rochelle, 2 rue Olympe de Gouges, $17000 \mathrm{La}$ Rochelle, France

4 GEODE (Géographie de l'environnement) UMR 5602 CNRS Université de Toulouse le Mirail, Maison de la Recherche, 5 Allées A. Machado, 31058 Toulouse Cedex 9, France parameters are fundamental to characterise the intensity of the fire: the paleotemperature reached at the surface of the burnt sediment (which in our case was determined by thermoluminescence analyses) and the depth of the rubefaction front as an indicator of a $250^{\circ} \mathrm{C}$ isothermal surface. We then estimated the duration of an equivalent single fire that would correspond to one of the archaeological hearths investigated. Finally, with the wood consumption recorded during the fire experiments, and the estimated firing duration, the energy involved was evaluated. When generalised to the study of archaeological hearths, this approach could be of great interest in firing intensity evaluation (temperature/time/energy).

Keywords Hearth · Experimental fire · Firing intensity · Paleotemperature $\cdot$ Energy $\cdot$ Heat propagation $\cdot$ Numerical modelling

\section{Introduction}

The karstic network of the cave of Les Fraux (Saint-Martinde-Fressengeas, Dordogne, France) was the starting point of our study. It was occupied during the Bronze Age (Carozza et al. 2009; Burens et al. 2014). The archaeological question about the function of the site and the mode of occupation of this cave was then addressed soon after its discovery. Indeed, this cave exhibits domestic remains such as occupation surfaces, combustion structures and ceramics, and rock art, ceramic and metal objects associated with ritual activity. Considering the remarkably high number and density of archaeological fires found in this karstic network, more than 60 (Fig. 1), and their importance in human occupations and activities, a specific study of the corresponding combustion structures was undertaken. 
Fig. 1 Map of the cave of Les Fraux showing location of all the combustion structures identified and probable ones, and areas with charcoals

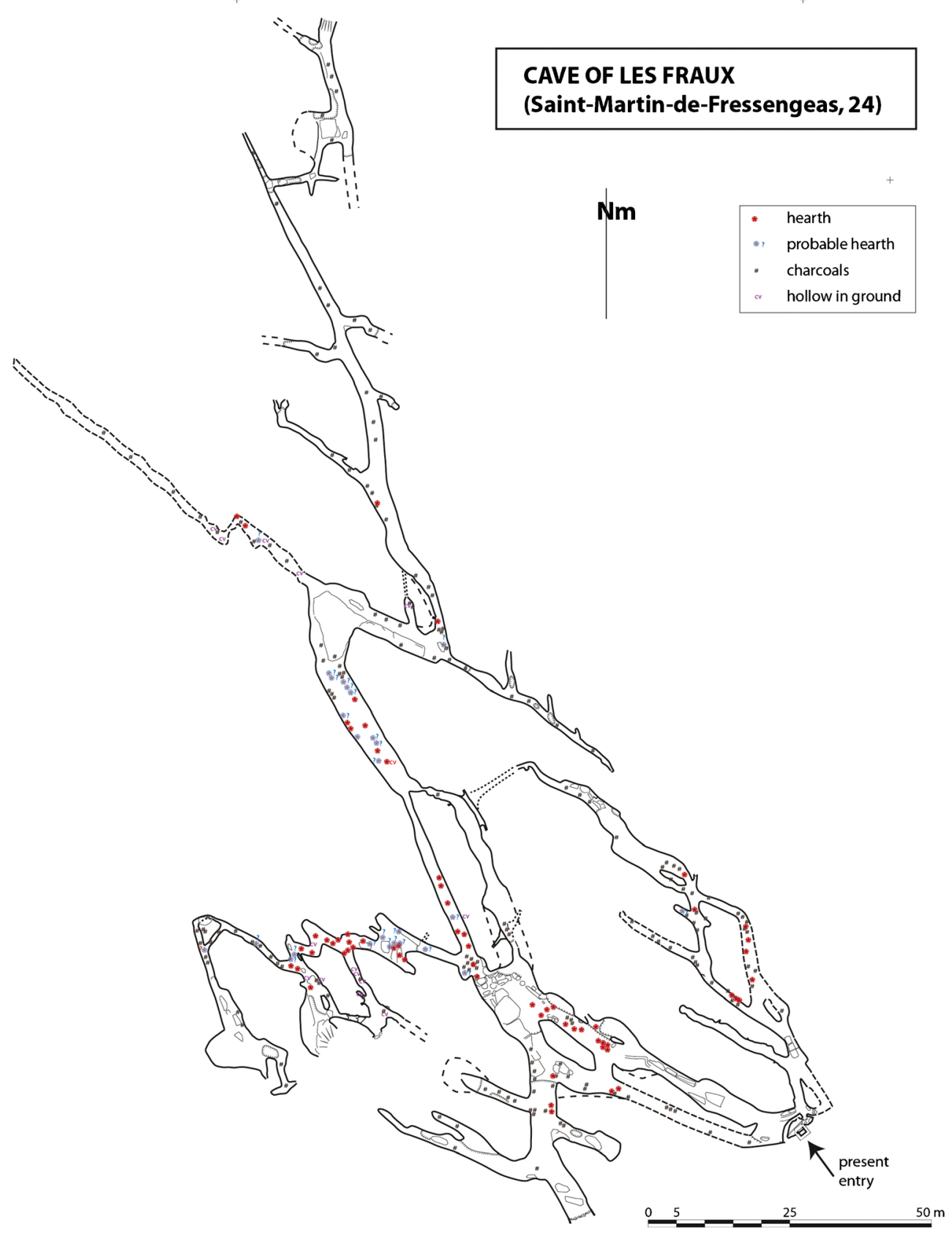

The main objective of our present study is to determine how it is possible to characterise the intensity of fires by studying their thermal impacts on their environment, and particularly on the sedimentary ground. Our results would constitute supplementary data about the archaeological fires to understand their roles, their operation, and their impact on an underground environment.

The usual approaches to the study of combustion structures are generally based on typological descriptions (Julien 1972; Leroi-Gourhan and Brezillon 1972; Leroi-Gourhan 1973; Beeching and Gascó 1989; Gascó 2003), analysis of fuel residues (Théry-Parisot 2002; Théry-Parisot and Texier 2006;
Conedera et al. 2009; Théry-Parisot and Henry 2012), micromorphological observations (Courty 1983, 1984; Wattez 1988, 1992; Goldberg and Berna 2010; Mentzer 2014) and archaeomagnetism measurements (Bellomo 1993; Carrancho and Villalaín 2011; Brodard et al. 2012).

As observations alone do not generally allow us to estimate firing intensity quantitatively, we aimed at developing a complementary approach. We started our methodological work from the results of a previous study of the heating state of superficial parts of combustion structure sedimentary substrates (Brodard et al. 2012; Brodard 2013). In these studies, we showed that thermoluminescence measurements provide 
paleothermometric data by estimating an equivalent paleotemperature attained for each sample of fired sediment, in comparison with thermal references. Nevertheless, the intensity of a fire cannot be defined only by the temperature attained by the supporting sediment. We also need an estimation of the fire duration and the quantity of energy released and injected into the sedimentary substratum. Building reference data is therefore a necessary step, and that was the reason why we undertook the building of a series of experimental fires.

In the final step, these experimental fires were numerically modelled into an idealised sedimentary structure using heat transfer calculations. By using modelling, we want to understand the modes of heat transfer in a substratum and isolate the most significant parameters in order to quantify thermal impacts on the substratum according to the amount of heat injected (i.e. quantity of wood consumed).

Despite the fact that only two different types of archaeological combustion structures were studied and then two experimental structures were built with a limited number of fires (3 in experiment \#1, 4 in experiment \#2), our present objective is to propose a new methodology to estimate the intensity of a fire that can be characterised by the temperature attained at the surface of a combustion structure, the fire duration and the energy involved.

\section{From the description of archaeological fires to the construction of experimental combustion features}

\section{Archaeological combustion structures}

The cave of Les Fraux was occupied during the Middle and Late Bronze Age only, through a period of time of about 2.5 centuries. There is no stratigraphy in the cave and this is probably the result of numerous occupations of short durations. The cave entrance collapsed during the Late Bronze 2, closing its access fossilising all the anthropogenic remains (combustion features, archaeological ground...). So no sedimentation covers the ancient fires or the other archaeological remains. In particular, the 62 fire areas identified, with a diameter always smaller than $50 \mathrm{~cm}$, are not covered or eroded and they are particularly well preserved thanks to the closure of the sole entrance to the cave.

We were particularly interested in investigating two archaeological fires (named F4 and F6) because they represent two main poles of distinct fire morphologies: One was designed with a shaped hearth and the second was set directly on the archaeological soil. They were also built on two different substrata, sandstone and clay, and presented different heat features at the surface of the sediment. In fact, a thermoluminescence approach had already been undertaken to determine the paleotemperature attained by the superficial sediment (Brodard 2013).

An important constraint to our work was that the cave of Les Fraux should be studied with the aim of maximal preservation of the remains, including the combustion structures. We are aware that two archaeological hearths represent only a small proportion of the fires observed in the cave of Les Fraux, but our aim is to develop and present a new methodology on two representative types of combustion features.

Fire F4 (Fig. 2) is an exceptional structure which consists of a shaped clayey hearth $(38 \mathrm{~cm}$ in diameter) located at the centre of an area with reddened altered sandstones and charcoals. On the surface of the shaped hearth, few cracks are visible. The substratum is made up of indurated sand on yellow blocks of sandstones which had collapsed from the walls and the ceiling of the cave.

Fire F6 (Fig. 3) is totally different both in typology and in the nature of the substratum. It is a simple open combustion structure $(30 \mathrm{~cm}$ in diameter) of reddened clay in a yellow clayey sediment area. In this clayey substratum, there are only occasional small sandstone blocks.

We recall that the thermoluminescence (TL) study cited above (Brodard et al. 2012; Brodard 2013), which is based on the comparison of intensity and shape of TL signals between archaeological fired samples and thermal references, allows the determination of paleotemperature for the two archaeological combustion structures studied. The main results are presented in Fig. 4 using a colour code. These paleotemperatures will be used later in this paper as comparison with the experimental recorded temperatures.

\section{About the justification of the reconstitution of experimental fires}

Studies based on experimental fires led to a better understanding of combustion structures and their uses. Among them, we

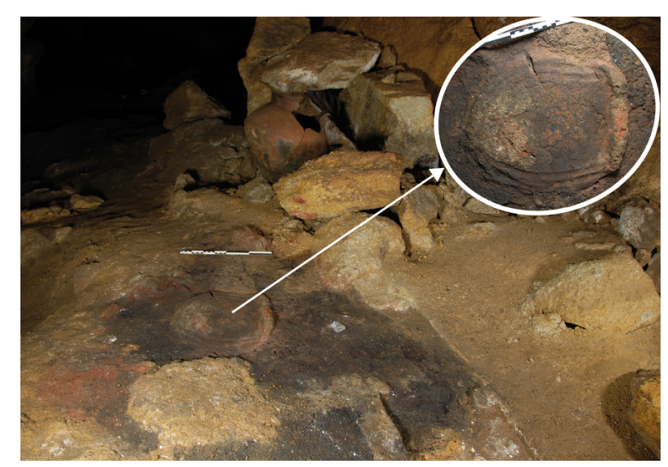

Fig. 2 Fire F4, sector 13, cave of Les Fraux. Shaped clayey hearth (38 $\mathrm{cm}$ in diameter) at the centre of an area with reddened altered sandstones and charcoals 


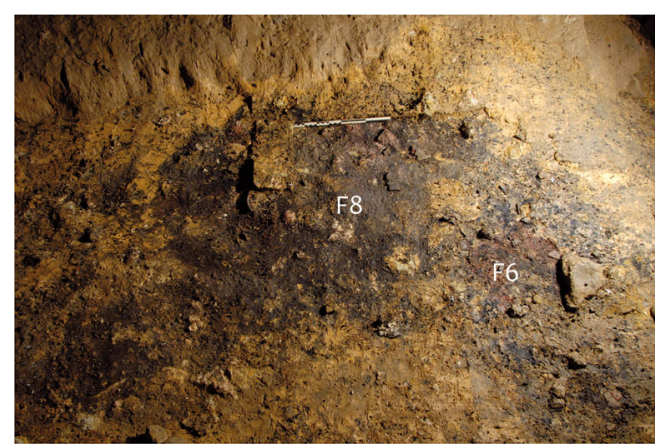

Fig. 3 Fires F6 and F8 (to the right of the picture), sector 13, cave of Les Fraux. F6 is a simple open combustion structure $(30 \mathrm{~cm}$ in diameter) of reddened clay in a yellow clayey sediment area. Occasional small sandstone blocks are present

present some of the main objectives that researchers have been interested in:

- The location of archaeological fires by the identification of combustion features: We have noticed four main methods for locating archaeological fires. The first one is based on modification of the colour of the soil (Canti and Linford 2000; Mallol et al. 2013a, b). Nevertheless, and according to these authors and our experience on other sites, if a soil colour modification (rubefaction) could suggest the presence of fire, the absence of visible rubefaction does not imply the absence of fire, since colour changes in some cases could be very weak. The second method is based on the spatial study of archaeological artefacts, for instance, lithic artefacts (Sergant et al. 2006; Alperson-Afil et al. 2007; Alperson-Afil 2012). Henry (2012) proposes a theoretical approach based on ring and sector methods (Stapert 1989) for the location of the combustion structure and the number of persons moving around it. Moreover, these studies suppose the presence of artefacts on the archaeological site and that they did not move after the fire. A third method to locate combustion structures is micromorphology (Goldberg and Berna 2010; Mentzer 2014), but it is invasive because it requires the extraction of at least one sample. Finally, the fourth method uses magnetic measurements (Carrancho et al. 2009; Carrancho and Villalaín 2011; Morinaga et al. 1999; Powell et al. 2012; Brodard 2013; Jrad et al. 2014) such as magnetic susceptibility or residual magnetisation. These measures are very useful for detecting heated sediments even if they are buried, but the temperature attained by the sediment has to be sufficient $\left(>250{ }^{\circ} \mathrm{C}\right)$ to induce mineral transformations and to increase the magnetic properties significantly.

- The impacts of fire on artefacts: Fire experiments were carried out as a source of heat to observe the thermal behaviour of materials, i.e. their capacity for heat retention and the thermal spalling (Backhouse and Johnson 2007). Some researchers (Brown et al. 2009; Mourre et al. 2010; Schmidt et al. 2012) studied the influence of fire on flaking properties. Schmidt et al. (2013) obtained reference data on heated silcrete. By performing experimental fires, Driscoll and Menuge (2011) found a way to differentiate heated vein quartz from unheated ones by the development of fluid escape structures induced by the decrepitation of fluid inclusions in quartz at more than $500{ }^{\circ} \mathrm{C}$.

- The determination of fuels: Besides classical studies of anthracology and micromorphology, the main aim of these experimental studies (Braadbaart et al. 2012; Gur-Arieh et al. 2013) was to deduce the original fuel-type, wood and/or dung, by determining the chemical composition of ashes and the ratio between the two types of micro calcite remains, pseudomorph or spherulite. Other researchers (Albert et al. 2000, 2003) have identified the type of combustible, wood or grass, from the study of phytoliths.

- The operation of different types of combustion structures: A first objective of this research was the energy properties, such as the heat released according to the nature of fuels (Braadbaart et al. 2012) or the heating power of an open fire inside a hut during winter (Liedgren and Östlund 2011) or the efficiency and function of a pit kiln (Sestier 2007). In addition, micromorphological
Fig. 4 Fires F4 (left), F6 and F8 (right) with indication of the paleotemperature attained by the superficial sediment, as a colour code. Paleotemperatures were measured by thermoluminescence experiments (Brodard et al. 2012; Brodard 2013). For F4, paleotemperatures were also determined for a small reddened area on the right of the shaped hearth
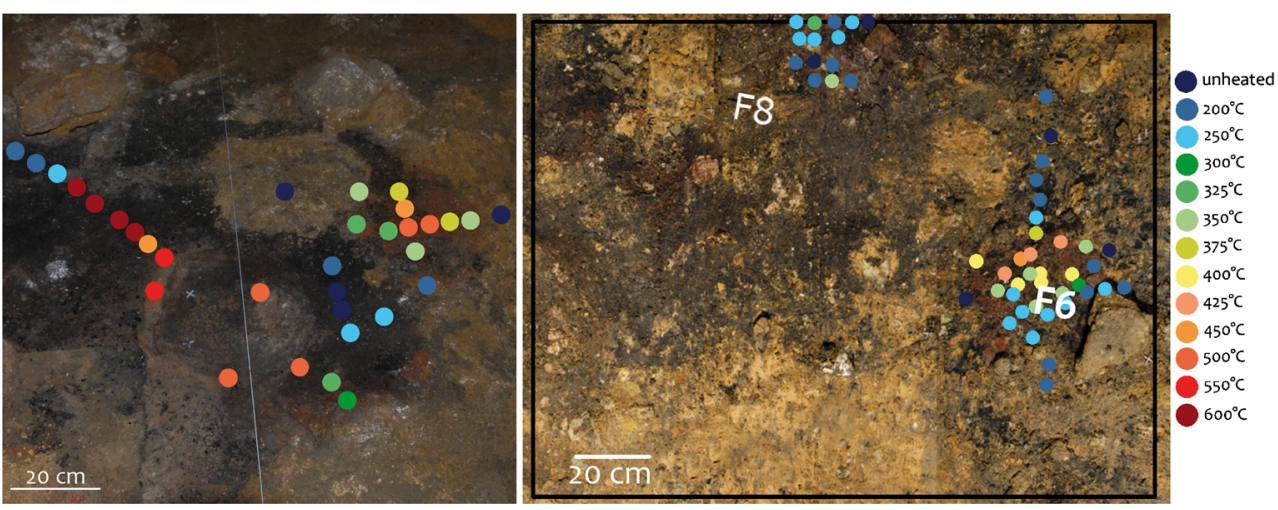
investigations could give some information about the function and the use of the fire like sweeping away the ashes and embers or on the contrary the existence of heaps of fire remains, and about its taphonomy such as trampling (Mallol et al. 2007; 2013a, b; Goldberg et al. 2009, 2012; Miller et al. 2010).

Based on comparative experimental fires, these studies provided data about the combustion operations, their location and their preservation, but none was interested in evaluating fire intensity as a combination of three parameters: temperature, duration and energy. Some studies were devoted to only one part of this trio, like temperature (Werts and Jahren 2007) or frequency and duration of use of a combustion structure (Bentsen 2012). It is therefore an innovative approach to exploit the thermal impacts recorded by the soil to define this intensity of firing. Finally, we want to use our experimental fires to obtain data about the temperature profile in the sediment, the speed of heat propagation and the quantity of wood consumed.

\section{Construction of experimental structures}

Two experimental structures were taken into consideration, aiming at reproducing both archaeological combustion features previously described. Each of them was equipped with a set of 20 thermocouples. The thermocouples are of type $\mathrm{K}$ (Chromel-Alumel) and can record temperatures up to $1200{ }^{\circ} \mathrm{C}$. They are connected to a data acquisition system (Agilent 34972A, Acquitek) composed of three 20-channel relay multiplexers. This system allows us to display and record data in real time: for each fire, the temperature was continuously recorded every $20 \mathrm{~s}$ for each thermocouple.

The first experimental structure (Fig. 5) reproduces the clayey substratum of archaeological fire F6. We used a square frame of $70 \mathrm{~cm}$ by $70 \mathrm{~cm}$ filled with clay. Considering the total volume of clay required, the local archaeological clay was replaced by one commercially available (Ceradel, CF141R) chosen for its ease of supply. This structure was built using small parallelepipeds of clay $(12 \mathrm{~cm} \times 12 \mathrm{~cm} \times 2$ or $4 \mathrm{~cm})$ set in four layers: the lowest one is $4 \mathrm{~cm}$ thick and the three upper ones are $2 \mathrm{~cm}$ thick. Twenty thermocouples were set between each layer (coordinates in Fig. 5).

Experimental structure \#2 (Fig. 6) is a reconstitution of archaeological fire F4. We used blocks of sandstone from the cave of Les Fraux for the first layer at the bottom. Then, we roughly crushed some blocks for the second layer. The third layer consists in finer crushed blocks of sandstone. Finally, we shaped a clayey hearth similar to that of fire F4 with clayey sediment from the cave of Les Fraux collected in sector $n^{\circ} 10$ (Fig. 1). The materials, sandstones and clay used in this structure are extracted from the cave and thus present a mineralogy close the archaeological sediment. As shown in
Fig. 6, 20 thermocouples were placed between the layers and within and above the shaped hearth.

\section{The firing experiments}

Three fires were set on the first experimental structure (clay) and four fires on the second (sandstone and sand). In the following section, we first describe the firing experiments and more precisely the choice of the type of wood, the duration of the fires, their number, their impact on the substratum and the recorded temperature.

\section{The wood}

The species that were identified by the anthracological study of charcoals from the cave of Les Fraux (Thiébault 2011) are beech, ash and oak. For these first fires, we used chestnut that was available at the time of our experiments and had calorific power close to beech, ash and oak. The pieces of chestnut used had dried for some years and no longer contain sapwood. The calorific power is about $15 \mathrm{MJ} / \mathrm{kg}$ for 20 weight $\%$ of humidity (Francescato et al. 2008: 25). This humidity weight percentage corresponds to that of a wood having dried for more than a year (Francescato et al. 2008: 47), and we will take it as a working value since we had not verified the water content of the wood provided. We chose to cut pieces of wood $30 \mathrm{~cm}$ in length and from 5 to $7 \mathrm{~cm}$ in diameter that were split into two or four. These dimensions were determined by the observed diameter of the archaeological combustion remains, around $30-40 \mathrm{~cm}$ : taller pieces of wood would have implied overimportant impacts on the substratum.

The wood was arranged in a pyramid-shaped assemblage. The fires were regularly fuelled to keep the combustion rate as constant as possible (no specific time intervals were fixed between each refuelling; it was more subjective: as soon as the combustion seemed to diminish, we refuelled the fire).

\section{The fires}

On experimental structure \#1 (clay substratum), three fires were set and were fuelled for $1 \mathrm{~h}$ and $20 \mathrm{~min}, 1 \mathrm{~h}$ and $45 \mathrm{~min}$, and $2 \mathrm{~h}$ respectively. Between fires 1 and 2, we waited for a night $(15 \mathrm{~h})$, and that allows the sediments to cool to room temperature. Between fires 2 and 3, only 2 or $3 \mathrm{~h}$ had elapsed so the sediments remained hot. Between each fire, we chose to clean the combustion surface after it had become cold by sweeping away ashes and charcoals even if, in the cave, there is no archaeological evidence of sweeping. The ashes are known to be a good insulator (Canti and Linford 2000), and we wanted to get the best thermal contact between fire and substratum. 

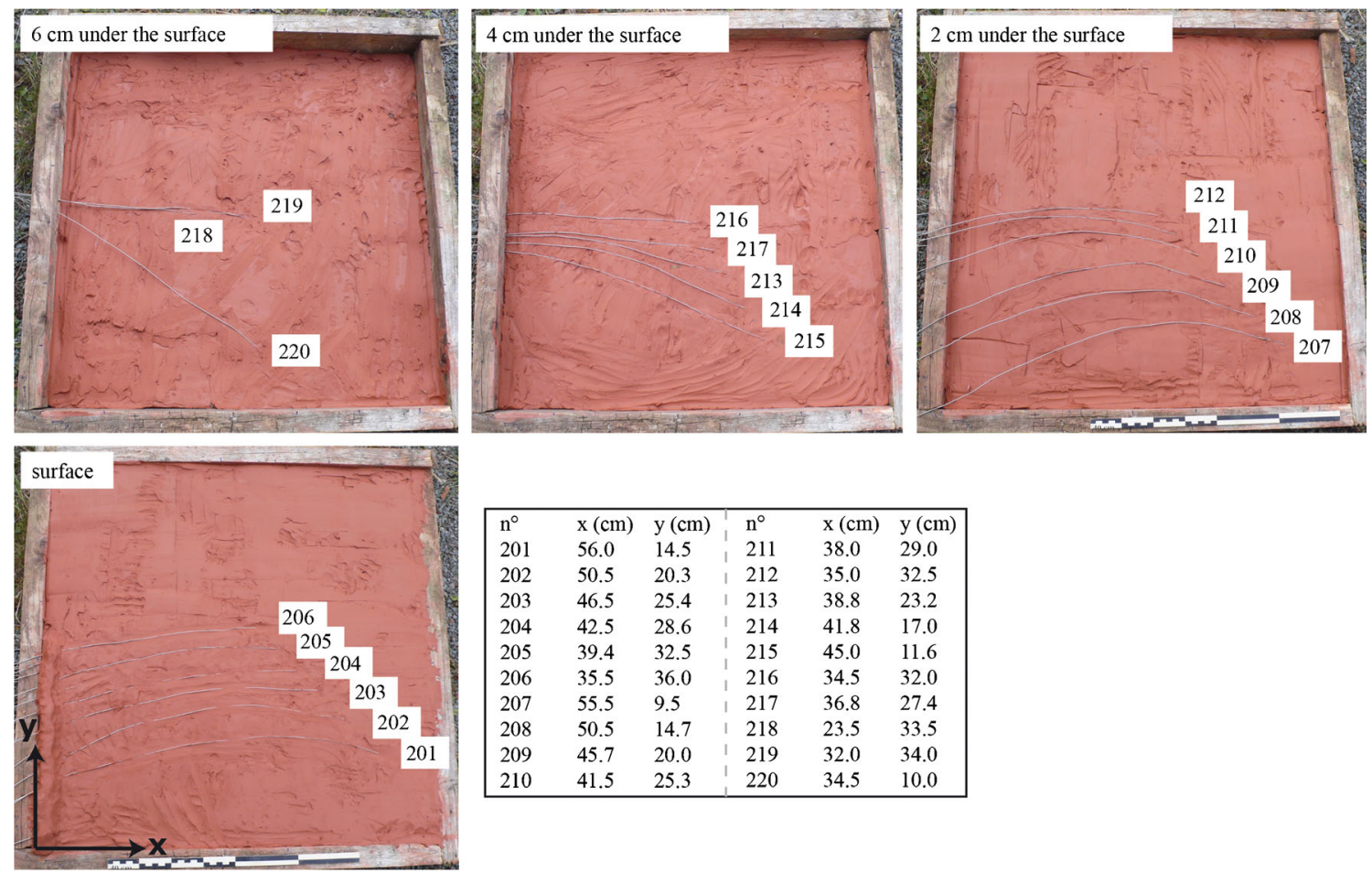

\begin{tabular}{|lll:lll|}
\hline $\mathrm{n}^{\circ}$ & $\mathrm{x}(\mathrm{cm})$ & $\mathrm{y}(\mathrm{cm})$ & $\mathrm{n}^{\circ}$ & $\mathrm{x}(\mathrm{cm})$ & $\mathrm{y}(\mathrm{cm})$ \\
201 & 56.0 & 14.5 & 211 & 38.0 & 29.0 \\
202 & 50.5 & 20.3 & 212 & 35.0 & 32.5 \\
203 & 46.5 & 25.4 & 213 & 38.8 & 23.2 \\
204 & 42.5 & 28.6 & 214 & 41.8 & 17.0 \\
205 & 39.4 & 32.5 & 215 & 45.0 & 11.6 \\
206 & 35.5 & 36.0 & 216 & 34.5 & 32.0 \\
207 & 55.5 & 9.5 & 217 & 36.8 & 27.4 \\
208 & 50.5 & 14.7 & 218 & 23.5 & 33.5 \\
209 & 45.7 & 20.0 & 219 & 32.0 & 34.0 \\
210 & 41.5 & 25.3 & 220 & 34.5 & 10.0 \\
\hline
\end{tabular}

Fig. 5 Experimental structure \#1, reproduction of fire F6 from the cave of Les Fraux (clayey substratum) and location of thermocouples (coordinate zero at the bottom left corner)

On experimental structure \#2 (sand substratum), four fires were lit. The first fire was fuelled for a total duration of $4 \mathrm{~h}$ and 15 min which included $3 \mathrm{~h}$ and 15 min of drying of the shaped clayey hearth with embers on it and burning wood at its periphery, and $1 \mathrm{~h}$ of fire actually set on the hearth. The other fires were set directly on the shaped hearth and respectively fuelled for $1 \mathrm{~h}$ and $40 \mathrm{~min}, 2 \mathrm{~h}$ and $20 \mathrm{~min}$ and $1 \mathrm{~h}$ and $45 \mathrm{~min}$. Between fires 1 and 2, and between fires 3 and 4, a night had elapsed (respectively $17 \mathrm{~h}$ and $30 \mathrm{~min}$, and $19 \mathrm{~h}$ ). Thus, the sediments cooled to room temperature. Between fires 2 and 3,
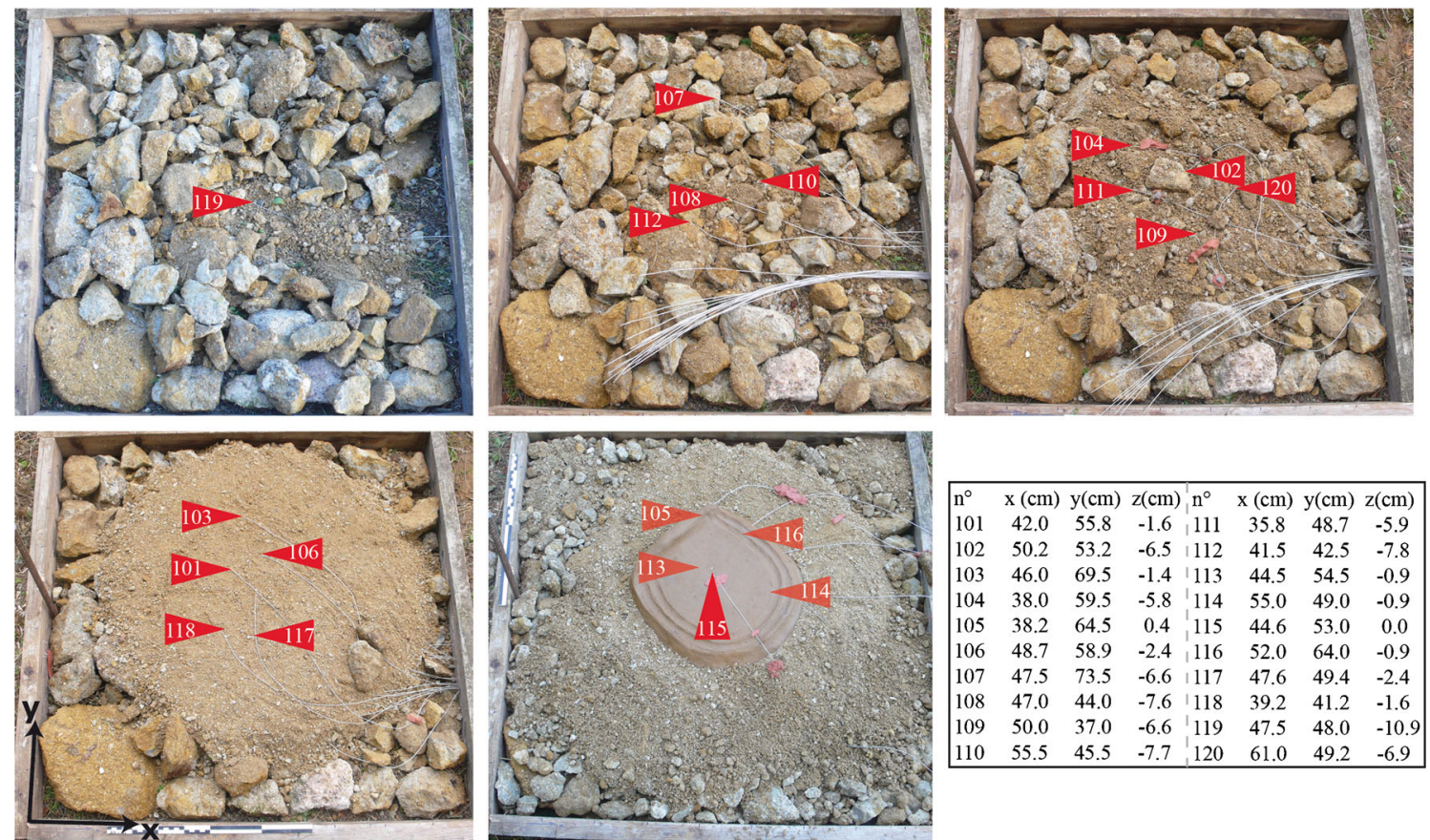

Fig. 6 Experimental structure \#2, reproduction of fire F4 from the cave of Les Fraux (clayey shaped hearth put on sandstones, crushed and in blocks) and location of thermocouples (zero for $x$ and $y$ in the bottom left corner; zero for $z$ at the surface of the shaped hearth) 
only $2 \mathrm{~h}$ elapsed and the sediments remained hot. For the first and the third fires, we left the ashes and charcoals until the entire cooling of the structure. For the second and the fourth fires, ashes and embers were removed, respectively $1 \mathrm{~h}$ and $40 \mathrm{~min}$, and $20 \mathrm{~min}$ after the last supply of wood. We removed them to try cooking meat on the hot, shaped hearth.

\section{The temperature curves, and the importance of water}

The temperature curves recorded during each fire are presented in Fig. 7. We can observe that, for the first fire, the temperature at the surface of each structure is about $500-600{ }^{\circ} \mathrm{C}$, whereas it is about $600-800{ }^{\circ} \mathrm{C}$ for the consecutive fires. In addition, there is also a plateau in the temperature at $100{ }^{\circ} \mathrm{C}$ for both substrata made with clay or sandstone. These observations are linked to the vaporisation of the soil or sediment water. During the first fire, a major part of the energy emitted by the combustion is used to evaporate water (heat vaporisation of water, $2257 \mathrm{~kJ} / \mathrm{kg}$ ) starting at the surface. The $100{ }^{\circ} \mathrm{C}$ water vaporisation plateaux are visible in all fires except fire 4 in structure $\# 2$. They persist as long as the sediments are wet and then, once dried, the temperature increases.

We also note that during fire 3 on the clay substratum, the temperature at $6-\mathrm{cm}$ depth is about $100{ }^{\circ} \mathrm{C}$. On the contrary, during fire 3 on sand substratum, the temperature at $6-\mathrm{cm}$ depth is about $300{ }^{\circ} \mathrm{C}$, and at more than $10-\mathrm{cm}$ depth, the temperature attains $150{ }^{\circ} \mathrm{C}$. In addition, we observe that the drying speeds are very different from one structure to the other (Table 1). For instance after $4 \mathrm{~h}$ of fire, only $2 \mathrm{~cm}$ of clay sediment has exceeded $100{ }^{\circ} \mathrm{C}$ whereas more than $8 \mathrm{~cm}$ of crushed sandstones was dried. This difference is partly due to the difference in the porosity of the materials: The sandstone substratum is more porous than clay so the water vapour can escape more rapidly from the heated substratum. Moreover, the clay substratum contains more water than the sandstone one, so more energy and time are needed to evaporate the

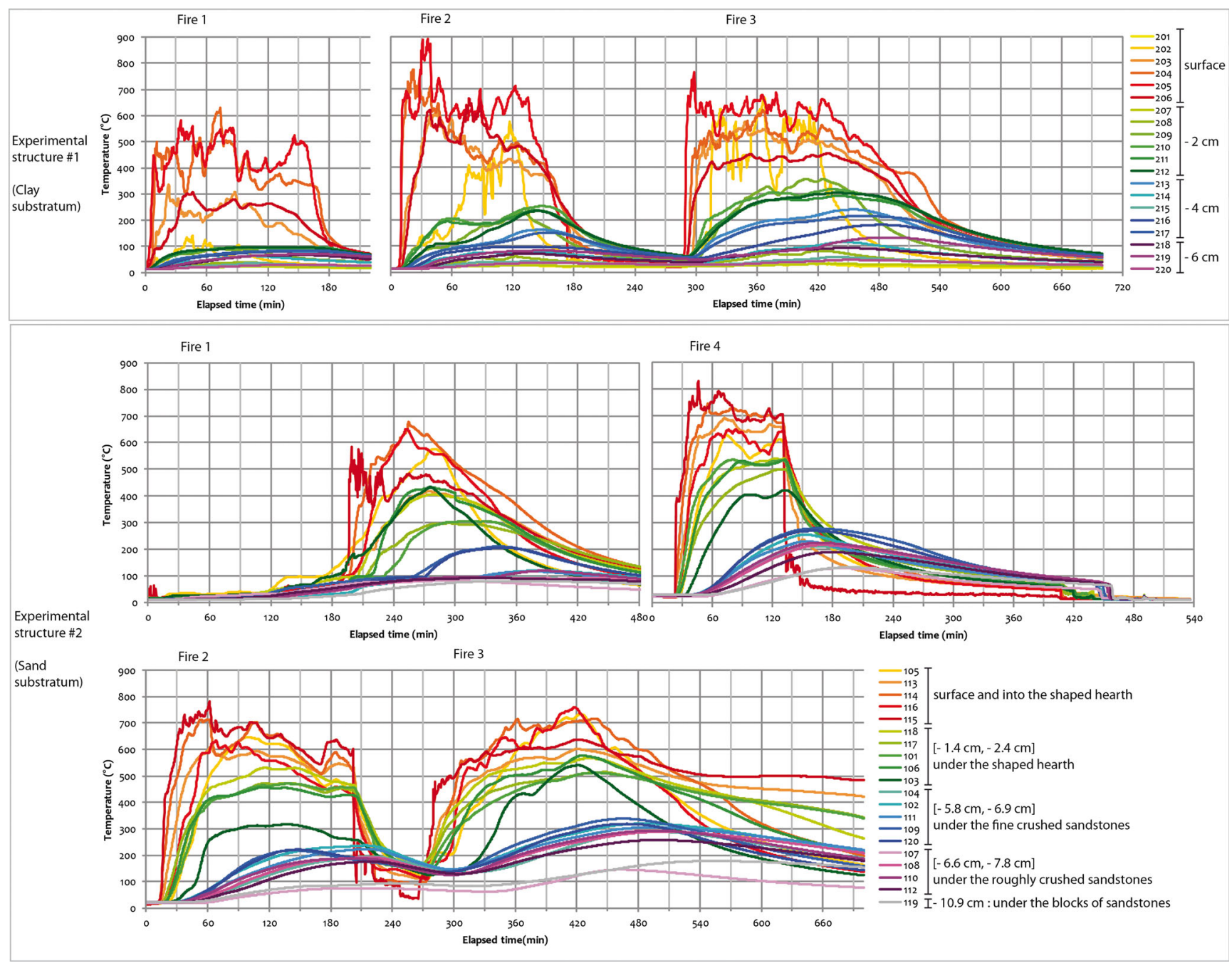

Fig. 7 Temperature curves recorded for each fire on the two experimental structures. The water vaporization plateaux at $100{ }^{\circ} \mathrm{C}$ are visible on both structures for the first fire experiments 
Table 1 Experimental data of the firing time allowing the temperature to exceed $100{ }^{\circ} \mathrm{C}$ for different depths of both combustion structures

\begin{tabular}{|c|c|c|c|c|c|c|c|}
\hline & Surface & $-1 \mathrm{~cm}$ & $-2 \mathrm{~cm}$ & $-4 \mathrm{~cm}$ & $-6 \mathrm{~cm}$ & $-8 \mathrm{~cm}$ & $-11 \mathrm{~cm}$ \\
\hline $\begin{array}{l}\text { Experimental structure \#1 } \\
\text { (clay substratum) }\end{array}$ & $10 \mathrm{~min}$ & & $4 \mathrm{~h}$ & $5 \mathrm{~h}$ & $9 \mathrm{~h}$ & & \\
\hline $\begin{array}{l}\text { Experimental structure \#2 } \\
\text { (sand substratum) }\end{array}$ & $1 \mathrm{~min}$ & $20 \mathrm{~min}$ & $30 \mathrm{~min}$ & & $1 \mathrm{~h}$ and $30 \mathrm{~min}$ & $3 \mathrm{~h}$ and $30 \mathrm{~min}$ & $7 \mathrm{~h}$ \\
\hline
\end{tabular}

water. From thermodynamic data, we calculated the energy required to pass from $\mathrm{RT}$ to $100{ }^{\circ} \mathrm{C}: 2.7 \mathrm{MJ} / \mathrm{kg}$ for water, including evaporation, compared to $\sim 0.1 \mathrm{MJ} / \mathrm{kg}$ of dry rock. For instance, a rock containing $10 \%$ of water (generally, the water saturation content of a soil is around $20 \%$ in weight) needs at least three times more energy than a dry one to go through the $100{ }^{\circ} \mathrm{C}$ plateau $(0.36 \mathrm{MJ} / \mathrm{kg}$ against $0.1 \mathrm{MJ} / \mathrm{kg}$ for dry rock).

Moreover, in Table 2, we reported the fuelling duration of each fire, the quantity of wood consumed, the calculated energy emitted by the combustion and the combustion speed (average quantity of wood consumed per hour). We see that for the fires on experimental structure \#1 (clay substratum), the speed of combustion is two times weaker than in the fires on structure \#2. This phenomenon is also linked to the different nature of the materials (clay or sandstone) composing the experimental substrata and the gradual drying state of these materials. Another observable consequence here is the increase in the combustion speed for each new fire on the same medium.

The multiple observations made about the temperature must be linked to the combustion speed, i.e. for the first fires, the combustion speed is slightly lower because, on the one hand, as the energy is mostly used to evaporate water, the substratum is cooler and the thermal radiation from the ground cannot heat the fuel as a feedback process; on the other hand, the large amount of water vapour emitted during the drying phases reduces oxygen partial pressure in a combustion atmosphere. On the contrary, once the sediments had become dry, the energy emitted by the combustion is used, for the most part, to support the combustion and to heat its environment: The highest combustion speed values correspond to the driest substrata (Table 2).

\section{Experimental combustion structures: observation, colour changes and cracks}

After the fire experiments, we observed colour modifications of sediments in the areas where the temperature exceeded $250{ }^{\circ} \mathrm{C}$. Cracks caused by drying of the clay were also observed (Fig. 8).

For experimental structure \#1 (clay substratum) and after the first fire, the baked clay showed only black and red colours where the embers were in contact. Around these areas, the clay was unchanged. We also observed some cracks that followed the edges of the parallelepipeds used to build the structure, but these are the consequence of construction weaknesses. During the second and third fires, the reddened area extended in depth, a ring of dried clay appeared and the cracks grew. After the third fire, we took down the structure. We observed a 6-cm-deep dried area in the middle of the fire, with a 2 -cm thickness of reddened clay on its superficial part (Fig. 9, left). Around this reddened area, the clay dried just $2 \mathrm{~cm}$ deep. Cracks were present in all the structure and the drying polygons were more numerous but smaller at the fire

Table 2 An assessment of combustion experiments: day and time of the beginning of fires, fuelled duration, mass of wood consumed, energy emitted (with $15 \mathrm{MJ} / \mathrm{kg}$ as an average value) and combustion speed

\begin{tabular}{|c|c|c|c|c|c|c|c|}
\hline \multirow{2}{*}{\multicolumn{2}{|c|}{ Experimental structure - fire }} & \multirow[t]{2}{*}{ Beginning of fire } & \multicolumn{2}{|l|}{ Fuelled duration } & \multirow{2}{*}{$\begin{array}{l}\text { Quantity of consumed } \\
\text { wood }(\mathrm{kg})\end{array}$} & \multirow[t]{2}{*}{ Emitted energy (MJ) } & \multirow{2}{*}{$\begin{array}{l}\text { Combustion } \\
\text { speed }(\mathrm{kg} / \mathrm{h})\end{array}$} \\
\hline & & & (h, min) & (h) & & & \\
\hline \multirow{3}{*}{$\begin{array}{l}\# 1 \\
\text { (clay substratum) }\end{array}$} & 1 & Day $1-17 \mathrm{~h}$ and $10 \mathrm{~min}$ & $1 \mathrm{~h}$ and $20 \mathrm{~min}$ & 1.33 & 4.6 & 69 & 3.5 \\
\hline & 2 & Day $2-10 \mathrm{~h}$ and $30 \mathrm{~min}$ & $1 \mathrm{~h}$ and $45 \mathrm{~min}$ & 1.75 & 6.3 & 95 & 3.6 \\
\hline & 3 & Day $2-15 \mathrm{~h}$ and $20 \mathrm{~min}$ & $2 \mathrm{~h}$ & 2.00 & 8.0 & 120 & 4.0 \\
\hline \multirow{4}{*}{$\begin{array}{l}\# 2 \\
\text { (sand substratum) }\end{array}$} & 1 & Day $1-12 \mathrm{~h}$ and $50 \mathrm{~min}$ & $4 \mathrm{~h}$ and $15 \mathrm{~min}$ & 4.25 & 28.0 & 420 & 6.6 \\
\hline & 2 & Day $2-10 \mathrm{~h}$ and $35 \mathrm{~min}$ & $1 \mathrm{~h}$ and $40 \mathrm{~min}$ & 1.67 & 11.5 & 173 & 6.9 \\
\hline & 3 & Day $2-14 \mathrm{~h}$ and $50 \mathrm{~min}$ & $2 \mathrm{~h}$ and $20 \mathrm{~min}$ & 2.33 & 19.5 & 293 & 8.4 \\
\hline & 4 & Day $3-11 \mathrm{~h}$ and $45 \mathrm{~min}$ & $1 \mathrm{~h}$ and $45 \mathrm{~min}$ & 1.75 & 12.8 & 192 & 7.3 \\
\hline
\end{tabular}




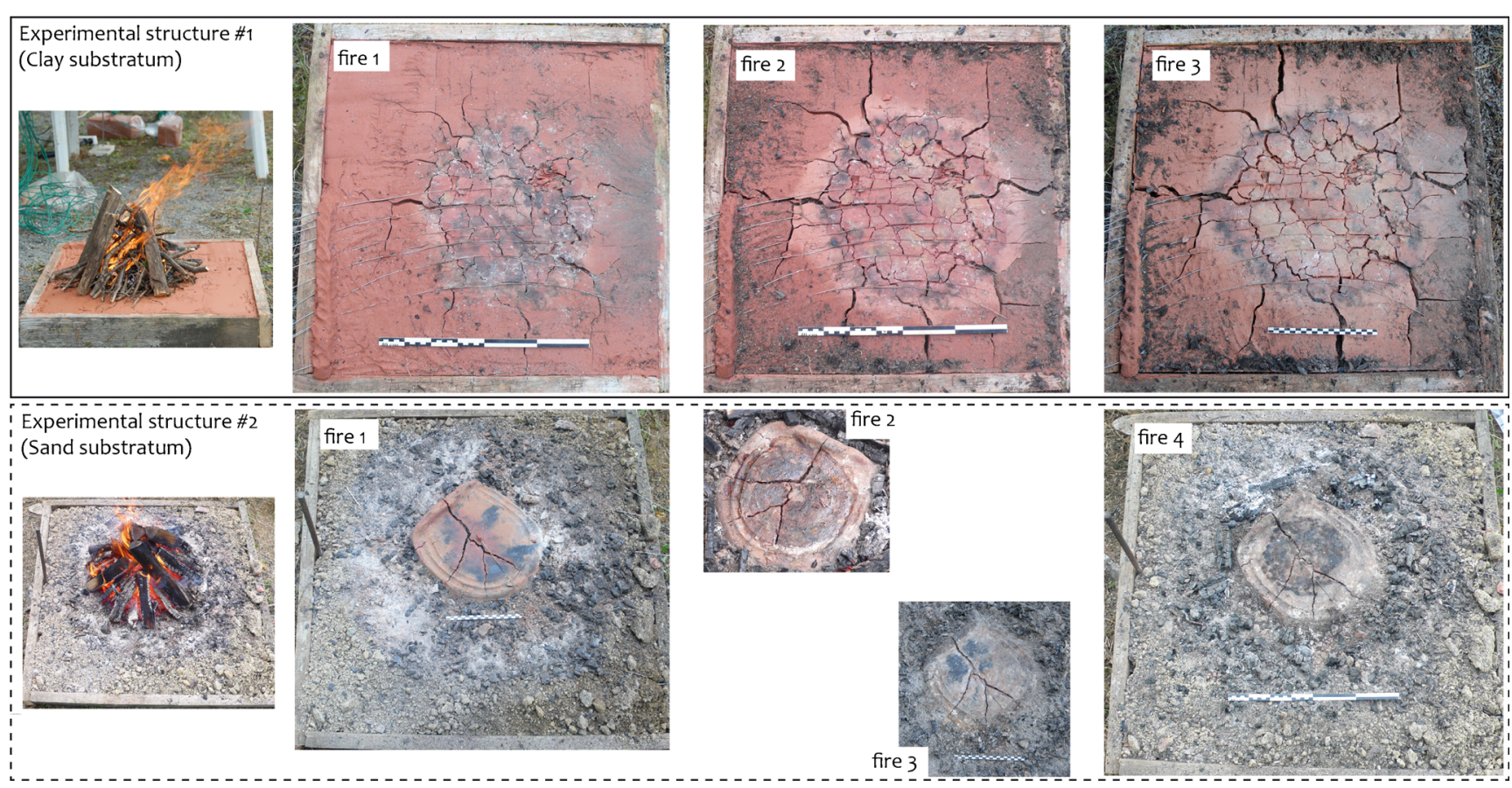

Fig. 8 A view of the progressive modifications of the surface of the two experimental structures

place rather than around it, probably in relation to the more important thermal gradient.

For experimental structure \#2 (sand substratum), the first fire caused colour modifications of the shaped hearth which became red and black, and also colour changes of the sandstones right under the embers that had been used to dry the shaped hearth (Fig. 8). The shaped hearth showed a few cracks pointing to both insufficient tempering and drying before firing. The three following fires did not increase the size and number of cracks, but the colour modifications continued in surface and depth. The 'meat cooking test' ${ }^{1}$ after the second and the fourth fires left mostly black marks of burnt fat on the hearth. After the fourth fire, we also took down the structure (Fig. 9, right). At the surface, we observe that the crushed sandstone right under the shaped hearth was strongly reddened. Around this area, the sandstones were slightly reddened (ring $15 \mathrm{~cm}$ wide), then only dried (colour observation) and, finally, still wet. When we looked in depth under the hearth, all the layers of crushed sandstones were reddened. But, the temperature attained in the sandstone blocks is not

\footnotetext{
${ }^{1}$ After the extinction of the second fire, we used the hearth, free from ashes, to cook two long sausages set in a spiral on it. The cooking of the sausage took a rather long time $(30 \mathrm{~min})$ because the hearth had cooled more rapidly than expected. It left a greasy layer on the entire hearth (Fig. 8). The third fire burnt this fat that left pluricentimetric black marks (Fig. 8) on half the surface of the hearth. After the fourth fire, we moved ashes and embers from the shaped hearth to get a hotter surface than after the second fire, and the time to cook a sausage at the same point as the preceding experiment was only $15 \mathrm{~min}$. It left also black marks in a circle form like the sausage (Fig. 8).
}

sufficient to redden them or even, at the very bottom of the structure, to dry them.

\section{Implications for the study of the archaeological fires}

\section{Temperature, reddened depth and cracks: comparison of archaeological and experimental combustion features}

\section{Comparison between TL paleotemperature and experimental recorded temperature}

Our previous thermoluminescence study (Brodard 2013) of archaeological fire F6 showed that temperatures of about $400-450{ }^{\circ} \mathrm{C}$ were attained at the most heated area. Around these hot zones, the temperature quickly dropped to $250{ }^{\circ} \mathrm{C}$ and below (Fig. 4). We recall that this thermal pattern only concerns the first centimetre of sediment in which the sample was taken for the TL study. Thus, the paleotemperature determined by TL is an average value within the first centimetre of sediment.

The experimental data of the reconstructed structure \#1 (clay substratum) are measured at the surface or at $2 \mathrm{~cm}$ deep (Fig. 7). If we use the data of the third fire, the maximal temperature at the surface varies between 450 and $650{ }^{\circ} \mathrm{C}$, so about $550{ }^{\circ} \mathrm{C}$ as an average value. At a depth of $2 \mathrm{~cm}$, the temperature is about $300{ }^{\circ} \mathrm{C}$. In addition, on the rim of the structure, the clay is just dried or still damp. 
Fig. 9 Taking down of experimental structures: clay on the left and sandstone on the right
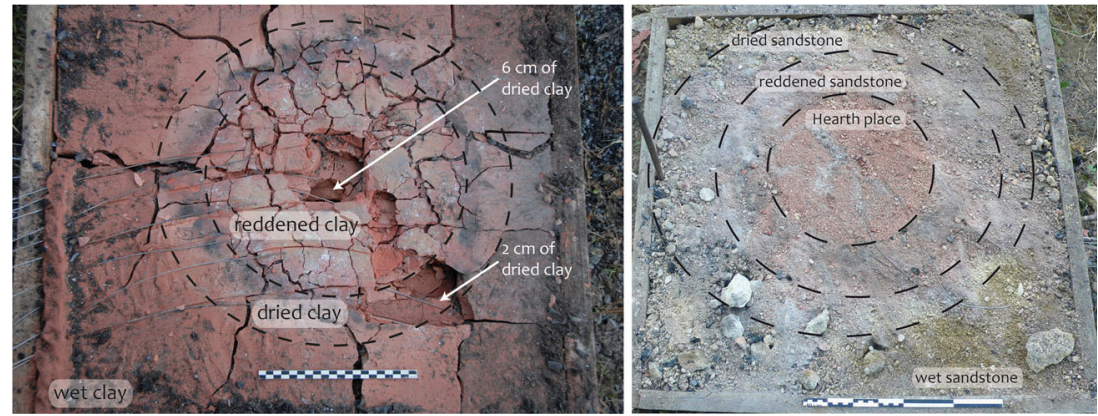

Archaeological paleotemperatures determined by TL are consistent with the data of experimental fires if we take into account the averaging of temperature within the first centimetre (Fig. 10).

For both archaeological structure F4 and experimental one \#2 (sand substratum), the temperature of the shaped hearth exceeded $500{ }^{\circ} \mathrm{C}$. We can see that just around the experimental shaped hearth, the sand is reddened $\left(T>250^{\circ} \mathrm{C}\right)$, and $20 \mathrm{~cm}$ further, we find unheated sediment (wet sandstone). This pattern matches well with the paleotemperatures found in front of and at the right of the archaeological shaped hearth (Fig. 4). At the back of hearth F4, the area presents a lot of charcoals and the paleotemperatures are quite high (it could be the place where the embers were set when the hearth was used by Bronze Age people).

In the framework of this study, the paleotemperatures determined by TL were corroborated by the temperatures recorded during the experiments, and thus, the TL method used is validated (for more details about this confirmation, see Brodard 2013).

\section{The reddened depths}

In connection with the temperature attained at the surface of the heated substrata (previous section), we can also compare the reddened depth. As a reference, 17 cubes of clay sediment extracted from the cave of Les Fraux were heated in an electric oven following these parameters: $20^{\circ} \mathrm{C} / \mathrm{min}$ for the heating speed, $1 \mathrm{~h}$ at the maximum temperature (stretched from 100 to $700{ }^{\circ} \mathrm{C}$ ) and $20^{\circ} \mathrm{C} / \mathrm{min}$ for the cooling speed. These series of

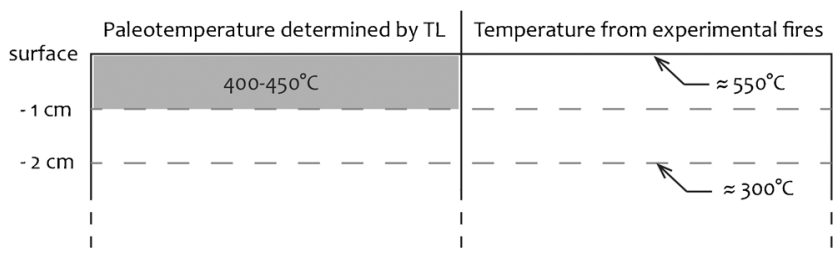

Fig. 10 Comparative sketch between archaeological paleotemperature (left) and temperature measured from experimental fires (right) respectively for F6 and the clayey experimental structure laboratory heatings show that the reddening due to transformations of iron oxi-hydroxides starts at $250{ }^{\circ} \mathrm{C}$ (Fig. 11). So we consider that the reddened depth is the depth of the substratum attained by the $250{ }^{\circ} \mathrm{C}$ temperature front. Because of the constraints of preservation, archaeological structure F4 was not sampled in depth so we cannot make the comparison with experimental structure \#2 (sand substratum). Nevertheless, as we used sediments extracted from the cave of Les Fraux to build experimental structure \#2, the colour changes between the archaeological sediments and the experimental ones are very similar.

On the contrary, for archaeological structure F6 and for archaeological structureexperimental structure \#1, the colours are not comparable because we used industrial clay and not the local one. However, for F6, some core samples showed a maximal reddened depth of $2.5 \mathrm{~cm}$. It also corresponds to the reddened depth of experimental structure \#1 (clay substratum).

\section{The cracks}

Contrary to the experimental clay fire structure, we do not observe cracks with archaeological one F6 and there is no archaeological evidence for a filling of possible cracks by unheated clay sediment. This absence of cracks in F6 could be the consequence of the permanent high humidity level inside the cave of Les Fraux (close to saturation, as in most caves). This implies a constant re-humidification of the heated sediment and the closure of the possible cracks

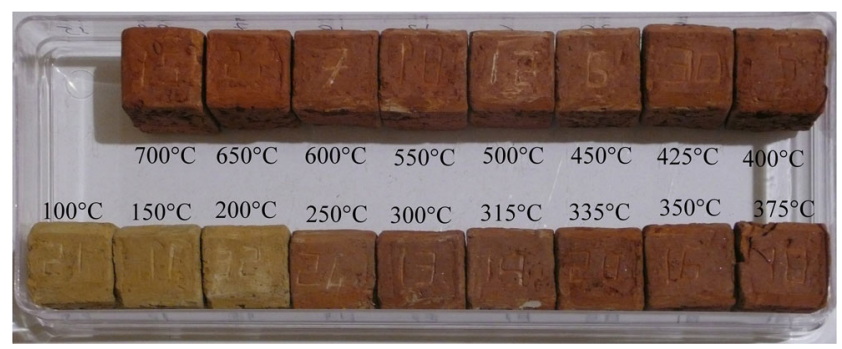

Fig. 11 Samples of sediments from the cave of Les Fraux heated in an electric oven for $1 \mathrm{~h}$ at each temperature from 100 to $700{ }^{\circ} \mathrm{C}$. The main colour modification appears at $250^{\circ} \mathrm{C}$ 
formed during heating. The cracks are the major difference in features between experimental and archaeological fire structures, and this could have been amplified by the weaknesses of construction of experimental fire \#1. For the archaeological shaped hearth (F4), a 1-cm-wide crack is still visible (Fig. 2) and comparable to those formed on the experimental shaped hearth (Fig. 8).

The comparison of temperature, reddened depth and cracks shows that we succeeded in reproducing experimental combustion features with thermal impacts similar to the archaeological ones, although our experiments were set in an open environment and not in a cave. To a certain extent, we must keep in mind that the containment induced by the underground situation can influence some parameters, notably the heating rate of atmosphere and walls, the circulation of fresh air, that of combustion gases and smokes and finally the supply of $\mathrm{O}_{2}$. Considering the number of archaeological fires observed and the paleotemperatures obtained, the air circulation should have been sufficient to supply the combustions in oxygen. In addition, it turns out that the water content of the substratum is one of the most significant parameters that control the heat propagation and thus the thermal impacts of the sediment, which is our concern here. Thus, the experimental fires constitute valid models for setting up the numerical modelling of heat propagation in sediment.

\section{From the numerical modelling of heat propagation to the estimation of firing duration}

We propose to use the experimental fires as models for archaeological ones regarding the energies involved and also to check for the ability of a numerical model of heat propagation in soil, in order to estimate the firing duration. This study has been undertaken in the particular case of a homogeneous sediment which corresponds to experimental structure \#1 (clay substratum) and by extension to archaeological fire F6.

\section{Numerical modelling of heat propagation}

The numerical code of the heat transfer used for the modelling is 'Thétis' (http://thetis.enscbp.fr/). Thétis is a research code for the modelling and the numerical simulation of fluid mechanics flows, and it was developed in the Institute of Mechanics and Mechanical Engineering of Bordeaux. It covers a large range of two or three dimensional physical problems: incompressible flows, laminar or turbulent, multiphase flows, thermal transfers and porous media.

The numerical model for the fire was built according to a 2D structure composed of three layers that represent three different states of drying observed for experimental structure \#1 (Fig. 12, left side). This is an important point because the difference in water content influences the thermophysical parameters (Oti et al. 2010):

- Thermal conductivity: Water $\left(\lambda=0.6 \mathrm{~W} \mathrm{~m}^{-1} \mathrm{~K}^{-1}\right)$ is a better heat conductor than air $\left(\lambda=0.026 \mathrm{~W} \mathrm{~m}^{-1} \mathrm{~K}^{-1}\right)$, so when the clay is drying, the water is replaced by the air and the material becomes a lesser conductor of heat.

- Calorific capacity: The product of the density by the calorific capacity increases with the water content (Oti et al. 2010; Lin et al. 2012).

- Quantity of heat: Quantity of heat necessary to vaporise all water is proportional to water content.

The modelling of heat propagation in a sediment containing water is very complex and would require thermophysical parameters dependent on time, depth and temperature (Muhieddine et al. 2011). Thus, the cut out structure in three layers allows us to simulate three states of drying in order to simplify the model by using constant parameters in each layer.

The thermal parameters to determine and input into the model are the thermal conductivity $\left(\lambda, \mathrm{W} \mathrm{m}^{-1} \mathrm{~K}^{-1}\right)$, the calorific capacity $\left(C p, \mathrm{~J} \mathrm{~kg}^{-1} \mathrm{~K}^{-1}\right)$ and the density $\left(\rho, \mathrm{kg} \mathrm{m}^{-3}\right)$. We chose to vary the thermal conductivity dependent on water content (Oti et al. 2010; Gualtieri et al. 2010) and to fix the
Fig. 12 Structure of the numerical model of experimental structure \#1 (clay substratum) in three layers (left side) and modelling of heat propagation after $2 \mathrm{~h}$ and $30 \mathrm{~min}$ of heating at $500{ }^{\circ} \mathrm{C}$ on the surface (right side)
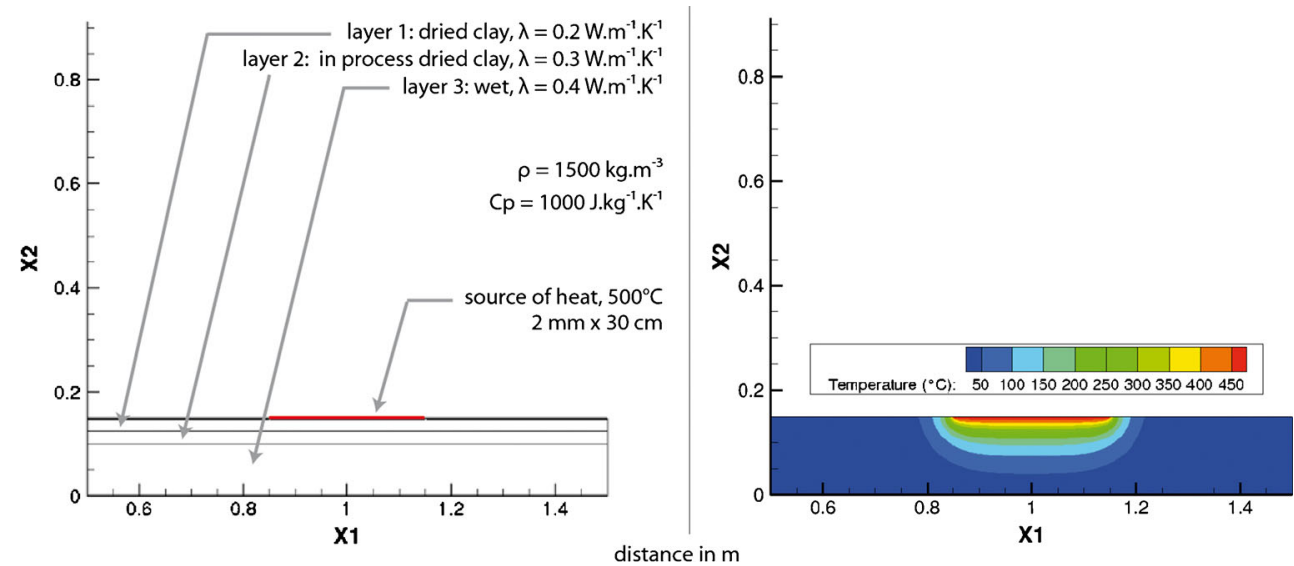
calorific capacity and the density with the following average values for clay sediment: $C p=1000 \mathrm{~J} \mathrm{~kg}^{-1} \mathrm{~K}^{-1}$ and $\rho=$ $1500 \mathrm{~kg} \mathrm{~m}^{-3}$.

To validate the model and find the consistent values of thermal conductivities of each layer, we used the temperature recorded during the third fire at structure \#1 (clay substratum). This fire was chosen because the sediment had begun to dry (three different layers) and the temperature was not wedged at $100{ }^{\circ} \mathrm{C}$.

So the fire is simulated by a source of heat set at a uniform and invariant temperature of $500{ }^{\circ} \mathrm{C}$ (Fig. 12). The modelling of heat propagation shows the temperature in the sediment at any moment. Based on bibliographical values of thermal conductivities (Oti et al. 2010; Gualtieri et al. 2010) and after dozens of tests, the values of thermal conductivities for having the best simulation of the experimental temperature by the modelling are as follows: $\lambda=0.2 \mathrm{~W} \mathrm{~m}^{-1} \mathrm{~K}^{-1}$ for the dried layer, $\lambda=0.3 \mathrm{~W} \mathrm{~m}^{-1} \mathrm{~K}^{-1}$ for the in process dried layer and $\lambda=0.4 \mathrm{~W} \mathrm{~m}^{-1} \mathrm{~K}^{-1}$ for the still wet layer.

Using this model, calibrated and adjusted with experimental values, we tried to reconstruct the thermal history of F6.

\section{Application to archaeological fire structure F6: heat propagation and an approach of the fire duration}

To approach the fire duration, two steps have to be considered:

- The time during which the sediments at the surface are drying. Based on our experimental fires, this minimal drying time before the temperature exceeds $100{ }^{\circ} \mathrm{C}$ is about $4 \mathrm{~h}$ on a clay structure (but, also according to our experimentations, it is only about $30 \mathrm{~min}$ for a shaped hearth on sandstones).

- $\quad$ The time during which the temperature begins to exceed $100^{\circ} \mathrm{C}$. A part of the sediment is dried, and the heat now allows an increase in the temperature at the surface and for the lower sediment to dry. The only proxy to approach this time is the reddened depth which corresponds to the propagation of the temperature front at $250{ }^{\circ} \mathrm{C}$ (Fig. 11).

The only archaeological structure where the reddened depth is known ( $2.5 \mathrm{~cm}$ at the most) is F6. The previous model was adjusted with the data from F6 to determine the time of heat propagation. Figure 13 shows the simulation of temperature variation in the substratum when the temperature of the source of heat applied at the surface is constant and equal to $500{ }^{\circ} \mathrm{C}$. We focused the representation on the points located at $2.5 \mathrm{~cm}$ on one hand and in the first centimetre on the other; the latter corresponds to the depth of sampling of archaeological combustion structures for the TL study.

A second simulation was carried out considering a surface temperature of $450{ }^{\circ} \mathrm{C}$. Figure 14 presents the temperatures attained in the substratum when the point at $2.5-\mathrm{cm}$ depth

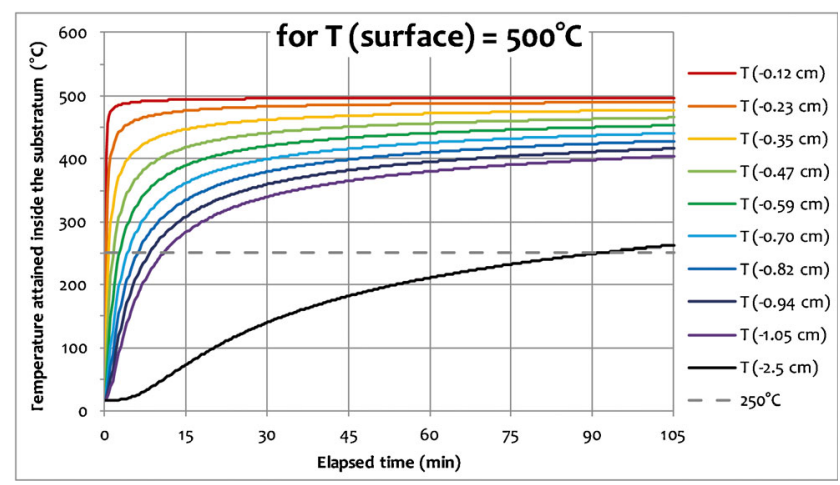

Fig. 13 Calculated variation with time of the temperature inside the modelled substratum of structure \#1 submitted to a surface temperature of $500{ }^{\circ} \mathrm{C}$

attained $250^{\circ} \mathrm{C}$, the temperature of rubefaction. The averaging temperature reached in the first centimetre of the structure is about 400 and $450{ }^{\circ} \mathrm{C}$ for surface temperature of 450 and $500{ }^{\circ} \mathrm{C}$ respectively. This latter is the most in agreement with the paleotemperature determined by TL for F6. Thus, we now consider the data of the simulation with the surface temperature at $500{ }^{\circ} \mathrm{C}$ in order to approach the firing duration. According to these data, $1 \mathrm{~h}$ and $30 \mathrm{~min}$ of heating on the substratum is necessary to reach $250{ }^{\circ} \mathrm{C}$ at 2.5 -cm depth. To this duration, we have to add the time needed to remove the water from the sediment, that is $4 \mathrm{~h}$. So we obtain a total duration of $5 \mathrm{~h}$ and $30 \mathrm{~min}$ of fire for structure F6.

To estimate the effect on this duration of a lower surface temperature, we calculated the firing duration for surface temperature varying between 400 and $500{ }^{\circ} \mathrm{C}$ (Fig. 15). We saw that a $50{ }^{\circ} \mathrm{C}$ uncertainty on TL paleotemperature implies a $50{ }^{\circ} \mathrm{C}$ uncertainty on the surface temperature (Fig. 14). So, for instance, if the paleotemperature of $\mathrm{F} 6$ was reduced to $400{ }^{\circ} \mathrm{C}$ instead of $450{ }^{\circ} \mathrm{C}$, the surface temperature would be $450{ }^{\circ} \mathrm{C}$ instead of $500{ }^{\circ} \mathrm{C}$, and the duration of heating would go up to $2 \mathrm{~h}$ and $5 \mathrm{~min}$ instead of $1 \mathrm{~h}$ and $30 \mathrm{~min}$ (Fig. 15), giving a total firing duration of $6 \mathrm{~h}$ instead of $5 \mathrm{~h}$ and $30 \mathrm{~min}$.

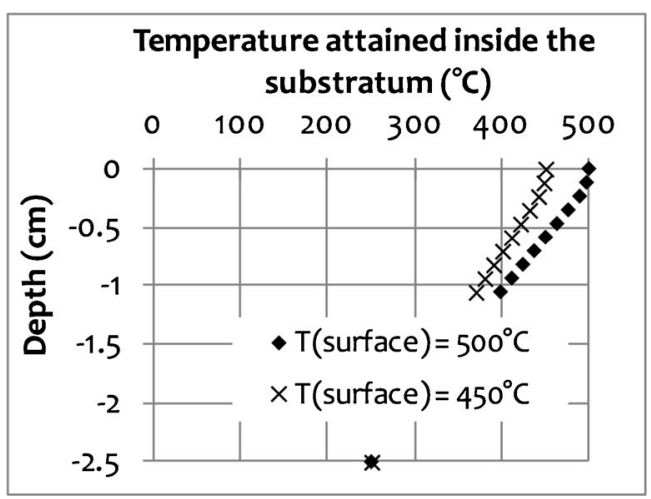

Fig. 14 Temperature profiles of the modelled substratum \#1 when the point at $2.5 \mathrm{~cm}$ depth is at $250{ }^{\circ} \mathrm{C}$ and for two different surface temperatures $\left(450\right.$ and $\left.500{ }^{\circ} \mathrm{C}\right)$ 


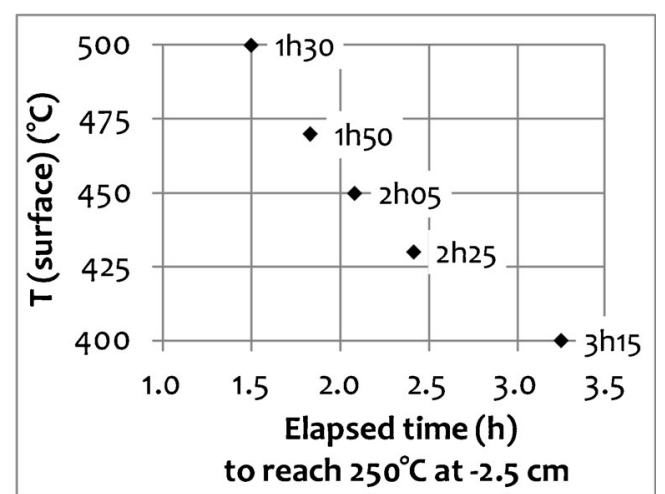

Fig. 15 Evolution with the surface temperature of the firing duration (time elapsed to reach $250{ }^{\circ} \mathrm{C}$ at $-2.5 \mathrm{~cm}$ )

In both calculations, the order of magnitude of the duration is stable and relevant.

Thus, for archaeological fire F6, the firing duration of $5 \mathrm{~h}$ $30 \mathrm{~min}(4 \mathrm{~h}+1 \mathrm{~h}$ and $30 \mathrm{~min})$ would be necessary to cause the observed impact of heat. If we consider that the thermal impacts observed for F6 are the result of one single fire, thus the time of $5 \mathrm{~h}$ and $30 \mathrm{~min}$ is a maximal duration of firing: Our calculation considers the sum of the drying from RT to $100{ }^{\circ} \mathrm{C}$ and the simulation from RT to elevated temperature. There is thus a slight overestimation of the time (about 20 min maximum) which corresponds to the 'simulation time' of heating from RT to $100{ }^{\circ} \mathrm{C}$. On the contrary, if we take the case of many fires with enough time between each of them to allow the re-humidification of the sediment, then the time of $5 \mathrm{~h}$ and $30 \mathrm{~min}$ is a minimal duration of firing since for each new fire, it is necessary to evaporate the sediment water before the increase in temperature beyond $100^{\circ} \mathrm{C}$. In the case of multiple fires, the question of the removal of ashes between two consecutive fires introduces a supplementary parameter that certainly influences the duration because of the insulating properties of ashes. Considering this discussion and the fact that it is not always possible to know if the combustion area was used many times, we must keep in mind that the duration of $5 \mathrm{~h}$ and $30 \mathrm{~min}$ is an equivalent time for a single fire.

\section{From wood consumption to energy emitted by the combustion}

The wood consumption is quite variable according to the experimental fire: about 3.5 to $4 \mathrm{~kg} / \mathrm{h}$ for structure \#1 (clay substratum) and about 6.7 to $8.4 \mathrm{~kg} / \mathrm{h}$ for structure \#2 (clay on sandstones). To express the wood consumption and the quantity of energy per time unit for archaeological fire F6, we used the experimental wood consumption of experimental structure \#1 (made with clay as for F6). Taking an average value of $3.8 \mathrm{~kg} / \mathrm{h}$, about $23 \mathrm{~kg}$ of chestnut wood used will be necessary for $6 \mathrm{~h}$ of continuous fire. This corresponds to energy of $345 \mathrm{MJ}$ for wood assuming water content of $20 \%$ in weight $(15 \mathrm{MJ} / \mathrm{kg})$.

\section{Conclusion}

In this paper, we have presented the description of two series of fire experiments and their results. The substratum of each experimental structure reproduces the type of substratum of archaeological combustion areas of the cave of Les Fraux (Dordogne). We succeeded in reproducing the thermal impacts observed for archaeological structures F4 and F6, namely, the temperature attained, the rubefaction and the cracks. The few differences, principally concerning the cracks, are linked to the environment, it being saturated with water in the cave and drier for the experimentation in the open medium.

Using these experiments, we proposed a new approach to characterise the intensity of fires based on thermal impacts recorded by sediments. As we have demonstrated, it is not possible to evaluate the intensity of fire only from a surface determination of paleotemperature. It is necessary to evaluate the duration parameter by the measurement of the reddened depth. It requires cutting core samples in ancient fires, which would make the study more destructive than initially planned. So, by comparing equivalent temperature and reddened depth of archaeological fires, with equivalent data from experimental ones and numerical modelling, we have been able to characterise the intensity of a fire by the following set of variables: temperature attained by the surface sediment, duration of the fire and the necessary quantity of wood, i.e. the quantity of energy involved.

This study pointed out the importance of the impact of the humidity of sediments on heat propagation and on wood consumption. This is a critical point for modelling, due to the thermodynamic discontinuities of the characteristics of water vaporisation. Here, we modelled the drying effects in a three layer model that was, according to us, the simplest means of operating. In its principle, this model could be used for all combustion structures set on clay substratum. This first model requires few adaptations to be extended to other substrata. Moreover, the way of determining the firing duration supposed a continuous heat (single fire).

In the cave of Les Fraux, only the reddened depth of fire F6 is known. At the present point, one can envisage a more exhaustive study of the combustion structures first to characterise the link between its morphology and the firing intensity, and second to identify some similarity between different combustion structures maybe according to their location in a gallery (with high or low ceiling) or in a room, and to their distance from the entrance.

Of course, it is essential to correlate our data with those of other specialists who study ancient fires (in our case, archaeology and anthracology) but also with the global study of the site. It is only by considering all the results as a whole that it will be possible to understand the roles of these fires, their operation in the underground environment and their impacts on the ground, the walls and the atmosphere of the cave. 
Acknowledgments We are particularly grateful to Edmond ${ }^{\dagger}$ and Marcelle Goineaud, owners of the cave, and to M. Fargeot, mayor of Saint-Martin-de-Fressengeas, for their help and trust in a colony of scientists.

This research was supported by the CNRS INEE (SEEG, cave of Les Fraux), CNRS-INSHS and partly by the CNRS AIR Archéométrie, and by the French Ministry of Culture and Communication (DRAC Aquitaine). University Bordeaux Montaigne gave a grant for Aurélie Brodard's $\mathrm{PhD}$. Additional support was provided by the ANR (Agence Nationale de la Recherche) labex LaScArBx (label of excellence Archaeological Sciences Bordeaux) from the ANR-10-LABEX-52 programme. We thank the two anonymous reviewers for their constructive comments that improved the first version of the manuscript.

\section{References}

Albert RM, Weiner S, Bar-Yosef O, Meignen L (2000) Phytoliths in the Middle Palaeolithic deposits of Kebara Cave, Mt Carmel, Israel: study of the plant materials used for fuel and other purposes. J Archaeol Sci 27(10):931-947

Albert RM, Bar-Yosef O, Meignen L, Weiner S (2003) Quantitative phytolith study of hearths from the Natufian and Middle Paleolithic levels of Hayonim cave (Galilee, Israel). J Archaeol Sci 30:461-480

Alperson-Afil N (2012) Archaeology of fire: methodological aspects of reconstructing fire history of prehistoric archaeological sites. Earth Sci Rev 113(3-4):111-119

Alperson-Afil N, Richter D, Goren-Inbar N (2007) Phantom hearths and the use of fire at Gesher Benot Ya'aqov, Israel. PaleoAnthropology 2007:1-15

Backhouse PN, Johnson E (2007) Where were the hearths: an experimental investigation of the archaeological signature of prehistoric fire technology in the alluvial gravels of the Southern Plains. J Archaeol Sci 34:1367-1378

Beeching A and Gascó J (1989) Les foyers de la Préhistoire récente du Sud de la France (descriptions, analyses, et essais d'interprétation). In: Olive $\mathrm{M}$ and Taborin $\mathrm{Y}$ dir., Nature et fonction des foyers préhistoriques, Actes du Colloque International de Nemours (1987), Mémoire du Musée de Préhistoire d'Île de France, Ed. APRAIF: 275-292

Bellomo RV (1993) A methodological approach for identifying archaeological evidence of fire resulting from human activities. J Archaeol Sci 20:525-553

Bentsen SE (2012) Size matters: preliminary results from an experimental approach to interpret middle stone age hearths. Quat Int 270:95-102

Braadbaart F, Poole I, Huisman HDJ, Van Os B (2012) Fuel, fire and heat: an experimental approach to highlight the potential of studying ash and char remains from archaeological contexts. J Archaeol Sci 39: 836-847

Brodard A (2013) Caractérisation thermique de structures de combustion par les effets de la chauffe sur les minéraux : thermoluminescence et propriétés magnétiques de foyers de la grotte des Fraux (Dordogne), Thèse de doctorat en Physique des Archéomatériaux, Université Michel de Montaigne, Bordeaux: 484 p. (https://tel.archivesouvertes.fr/tel-00870483)

Brodard A, Guibert P, Lévêque F, Mathé V, Carozza L, Burens A (2012) Thermal characterization of ancient hearths from the cave of Les Fraux (Dordogne, France) by thermoluminescence and magnetic susceptibility measurements. Quat Geochronol 10:353-358

Brown KS, Marean CW, Herries AIR, Jacobs Z, Tribolo C, Braun D, Roberts DL, Meyer MC, Bernatchez J (2009) Fire as an engineering tool of early modern humans. Science 325:859-862

Burens A, Grussenmeyer P, Carozza L, Lévêque F, Guillemin S, Mathé V (2014) Benefits of an accurate 3D documentation in understanding the status of the bronze age heritage cave « Les Fraux » (France). Int J Herit Stud Digit Era 3(1):179-195

Canti MG, Linford N (2000) The effects of fires on archaeological soils and sediments: temperature and colour relationships. Proc Prehist Soc 66:385-395

Carozza L, Burens A, Billaud Y, Ferullo O, Bourrillon R, Petrognani S, Tosello G, Goineaud E\&M (2009) L'horizontal et le vertical - L'Âge du bronze de la grotte des Fraux (Saint-Martin-de-Fressengeas Dordogne). In: De méditerranée et d'ailleurs... Mélanges offerts à Jean Guilaine, Archives d'Ecologie Préhistorique, Toulouse: 159172,8 fig

Carrancho Á, Villalaín JJ (2011) Different mechanisms of magnetisation recorded in experimental fires: Archaeomagnetic implications. Earth Planet Sci Lett 312(1):176-187

Carrancho A, Villalaín JJ, Angelucci DE, Dekkers MJ, Vallverdú J, Vergès JM (2009) Rockmagnetism analyses as a tool to investigate archaeological fired sediments: a case study of Mirador cave (Sierra de Atapuerca, Spain). Geophys J Int 17:79-93

Conedera M, Tinner W, Neff C, Meurer M, Dickens AF, Krebs P (2009) Reconstructing past fire regimes: methods, applications, and relevance to fire management and conservation. Quat Sci Rev 28:555576

Courty M-A (1983) Interprétation des aires de combustion par la micromorphologie. Bulletin de la Société Préhistorique Française 80:169171

Courty M-A (1984) Formation et évolution des accumulationscendreuses : approche micromorphologique, Influences méridionales dans l'Est et le Centre-Est de la France au Néolithique : le rôle du Massif central, Actes du $8^{\mathrm{e}}$ colloque interrégional sur le Néolithique, Le Puy-en-Velay, 3-4 oct. 1981, Centre de Recherche et d'Étudespréhistoriques de l'Auvergne (CREPA), cahier 1, Clermont-Ferrand: 341-353

Driscoll K, Menuge J (2011) Recognising burnt vein quartz artefacts in archaeological assemblages. J Archaeol Sci 38:2251-2260

Francescato V, Antonini E, Zuccoli Bergomi L (2008) Wood fuels handbook. AIEL - Italian Agriforest Energy Association: 83 p. http:// www.aebiom.org/IMG/pdf/WOOD_FUELS_HANDBOOK_BTC EN.pdf

Gascó J (2003) Propositions de vocabulaire. In: M.-C. Frère-Sautot dir., Le feu domestique et ses structures au Néolithique et aux Âges des Métaux, Actes du colloque de Bourg-en-Bresse et Beaune, 78octobre 2000, coll. Préhistoires, 9, éd. Monique Mergoil, Montagnac:109-112

Goldberg P, Berna F (2010) Micromorphology and context. Quat Int 214: $56-62$

Goldberg P, Miller C, Schiegl S, Ligouis B, Berna F, Conard NJ, Wadley L (2009) Bedding, hearths, and site maintenance in the Middle Stone Age of Sibudu Cave, KwaZulu-Natal, South Africa. Archaeol Anthropol Sci 1:95-122

Goldberg P, Dibble H, Berna F, Sandgathe D, McPherron SJP, Turq A (2012) New evidence on Neanderthal use of fire: examples from Roc de Marsal and Pech de l'Azé IV. Quat Int 247:325-340

Gualtieri ML, Gualtieri AF, Gagliardi S, Ruffini P, Ferrari R, Hanuskova M (2010) Thermal conductivity of fired clays: effects of mineralogical and physical properties of the raw materials. Appl Clay Sci 49: 269-275

Gur-Arieh S, Mintz E, Boaretto E, Shahack-Gross R (2013) An ethnoarchaeological study of cooking installations in rural Uzbekistan: development of a new method for identification of fuel sources. J Archaeol Sci 40(12):4331-4347

Henry D (2012) The palimpsest problem, hearth pattern analysis, and Middle Paleolithic site structure. Quat Int 247:246-266

Julien M (1972) Témoins relatifs au feu. Fouilles de Pincevent. Essai d'analyse ethnographique d'un habitatmagdalénien. (la section 36) $7^{\text {ème }}$. Supplément Gallia Préhistoire. C.N.R.S. France 
Jrad A, Quesnel Y, Rochette P, Jallouli C, Khatib S, Boukbida H, Demory F (2014) Magnetic Investigations of Buried Palaeohearths Inside a Palaeolithic Cave (Lazaret, Nice, France). Archaeol Prospect 21: 87-101

Leroi-Gourhan A (1973) Séminaire sur les structures d'habitat, les témoins de combustion. Collège de France, Laboratoire d'Ethnologie Préhistorique, Paris, n52, 43 p

Leroi-Gourhan A and Brezillon M (1972) Fouilles de Pincevent. La section 36. Essai d'analyse ethnographique d'un habitat magdalénien. Gallia préhistoire, supplément 7, CNRS Ed. 2 volumes, 331 p., 199 fig

Liedgren LG, Östlund L (2011) Heat, smoke and fuel consumption in high mountain stállo-hut, northern Sweden - Experimental burning of fresh birch wood during winter. J Archaeol Sci 38:903-912

Lin J, Grandgeorge J-D, Braymand S, Fond C (2012) Caractérisation thermique des sols pour le régime transitoire. $2^{\text {ème }}$ colloque de la construction durable dans le Rhin Supérieur, Strasbourg (15 novembre 2012)

Mallol C, Marlowe FW, Wood BM, Porter CC (2007) Earth, wind, and fire: ethnoarchaeological signals of Hadza fires. J Archaeol Sci 34: 2035-2052

Mallol C, Hernandez CM, Cabanes D, Machado J, Sistiaga A, Pérez L, Galvan B (2013a) Human actions performed on simple combustion structures: an experimental approach to the study of Middle Palaeolithic fire. Quat Int 315:3-15

Mallol C, Hernandez CM, Cabanes D, Sistiaga A, Machado J, Rodriguez A, Pérez L, Galvan B (2013b) The black layer of Middle Palaeolothic combustion structures. Interpretation and archaeostratigraphic implications. J Archaeol Sci 40:2515-2537

Mentzer C (2014) Microarchaeological approaches to the identification and interpretation of combustion features in prehistoric archaeological sites. J Archaeol Method Theory 21(3):616-668

Miller CE, Conard NJ, Goldberg P, Berna F (2010) Analyse micromorphologique de structures de combustion expérimentales anthropiquement remaniées. In: Théry-Parisot I, Chabal L, Costamagno $\mathrm{S}$ dir., Taphonomie de la combustion des résidus organiques et des structures de combustion en contexte archéologique., Valbonne (27-29 mai 2008), P@leoethnologie 2: 25-37

Morinaga H, Inokuchi H, Yamashita H, Ono A, Inada T (1999) Magnetic detection of heated soils at Paleolithic sites in Japan. Geoarchaeology 14(5):377-399

Mourre V, Villa P, Henshilwood CS (2010) Early use of pressure flaking on lithic artifacts at Blombos Cave, South Africa. Science 330:659662

Muhieddine M, Canot E, March RJ, Delannay R (2011) Coupling heat conduction and water-steam flow in saturated porous medium. Int $\mathrm{J}$ Numer Methods Eng 85:1390-1414

Oti JE, Kinuthia JM, Bai J (2010) Design thermal values for unfired clay bricks. Mater Des 31:104-112
Powell AJ, Wheeler J, Batt CM (2012) Identifying archaeological wood stack charcoal production sites using geophysical prospection: magnetic characteristics from a modern wood stack charcoal burn site. J Archaeol Sci 39:1197-1204

Schmidt P, Masse S, Laurent G, Slodczyk A, Le Bourhis E, Perrenoud C, Livage J, Fröhlich F (2012) Crystallographic and structural transformations of sedimentary chalcedony in flint upon heat treatment. J Archaeol Sci 39:135-144

Schmidt P, Porraz G, Slodczyk A, Bellot-Gurlet L, Archer W, Miller CE (2013) Heat treatment in the South African Middle Stone Age: temperature induced transformations of silicrete and their technological implications. J Archaeol Sci 40:3519-3531

Sergant J, Crombé P, Perdaen Y (2006) The 'invisible' hearths: a contribution to the discernment of Mesolithic non-structured surface hearths. J Archaeol Sci 33:999-1007

Sestier C (2007) Etude du profil thermique d'une structure de combustion en meule (pitkiln): four ou foyer simple ? In Fire as an Instrument: The Archaeology of Pyrotechnologies, D. Gheorghiu dir.: 25-31

Stapert D (1989) The ring and sector method, intrasite spatial analysis of Stone Age sites, with special reference to Pincevent. Palaeohistoria 31:1-57

Théry-Parisot I (2002) Fuel management (bone and wood) during the lower Aurignacian in the Pataud rock shelter (lower palaeolothic, Les Eyzies de Tayac, Dordogne, France). Contribution of experimentation. J Archaeol Sci 29:1415-1421

Théry-Parisot I, Henry A (2012) Seasoned or green? Radial cracks analysis as a method for identifying the use of green wood as fuel in archaeological charcoal. J Archaeol Sci 39:381-388

Théry-Parisot I, Texier P-J (2006) La collecte du bois de feu dans le site moustérien de la Combette (Bonnieux, Vaucluse, France): implications paléo-économiques et paléo-écologiques. Approche morphométrique des charbons de bois. Bulletin de la Société Préhistorique Française 103(3):453-463

Thiébault S (2011) Résultats préliminaires de l'identification des charbons de bois de la grotte des Fraux - Données anthracologiques pour une approche de l'environnement végétal ligneux. In Carozza L (2011), L'âge du Bronze de la grotte des Fraux - Saint-Marin-deFressengeas (Dordogne). Rapport de fouille programmée annuelle, Service Régional de l'Archéologie d'Aquitaine, Bordeaux: 98 p

Wattez J (1988) Contribution à la connaissance des foyers préhistoriques par l'étude des cendres. Bulletin de la Société Préhistorique Française 85:352-356

Wattez J (1992) Dynamique de formation des structures de combustion de la fin du Paléolithique au Néolithique moyen. Approche méthodologique et implications. Thèse nouveau régime, Université Paris $1,438 \mathrm{p}$

Werts SP, Jahren AH (2007) Estimation of temperature beneath archaeological campfires using carbon stable isotope composition of soil organic matter. J Archaeol Sci 34:850-857 